Supporting Information

\title{
One-Step Construction of $\mathrm{MoS}_{0.74} \mathrm{Se}_{1.26} / \mathrm{N}$-Doped Carbon Flowerlike Hierarchical Microspheres with Enhanced Sodium Storage
}

Nianxiang Shi, ${ }^{a}$ Baojuan Xi, ${ }^{a}$ Man Huang, ${ }^{a}$ Fang Tian, ${ }^{a}$ Weihua Chen, ${ }^{b}$ Haibo Li, $^{c}$ Jinkui Feng, ${ }^{d}$ and Shenglin Xiong*a

a Key Laboratory of Colloid and Interface Chemistry, Ministry of Education, School of Chemistry and Chemical Engineering, and State Key Laboratory of Crystal Materials, Shandong University, Jinan 250100, P. R. China

b College of Chemistry and Molecular Engineering, Key Laboratory of Material Processing and Mold of Ministry of Education, Zhengzhou University, Zhengzhou 450001, P. R. China

c School of Chemistry and Chemical Engineering, Liaocheng University, Liaocheng, Shandong 252059, P. R. China

d Key Laboratory for Liquid-Solid Structural Evolution \& Processing of Materials (Ministry of Education), School of Materials Science and Engineering, Shandong University, Jinan 250061, P. R. China

Correspondence and requests for materials should be addressed to S.L.X. (email: chexsl@sdu.edu.cn). 


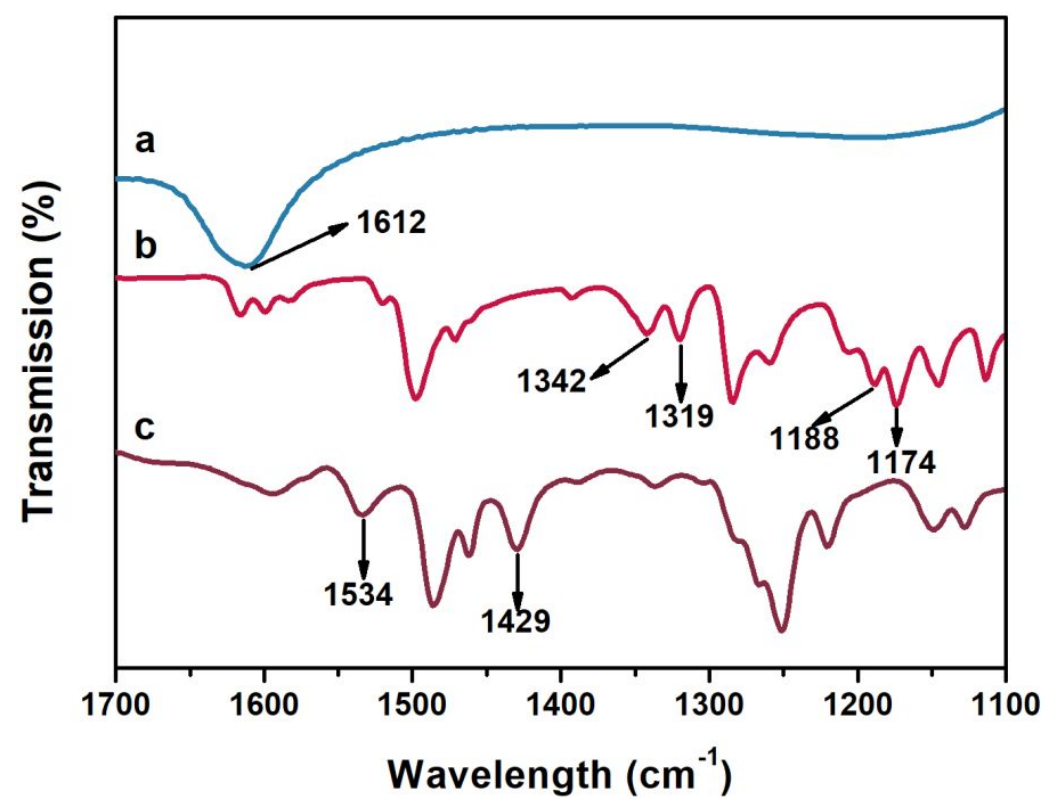

Figure S1. The FTIR spectra of (a) phosphomolybdic acid, (b) dopamine hydrochloride, and (c) Mo-polydopamine hybrid.

Note: As shown in Figure S1, curves a-c are FTIR spectra of phosphomolybdic acid, dopamine hydrochloride and Mo-polydopamine hybrid, respectively. Curve a has a broad absorption band at $1612 \mathrm{~cm}^{-1}$, which belongs to $\mathrm{O}-\mathrm{H}$ stretching vibration. ${ }^{1,2}$ From the FTIR spectrum of dopamine hydrochloride (curve b), we can see that four adsorption peaks are centered at 1342,1319, 1188 and $1174 \mathrm{~cm}^{-1}$, which can be attributable to $\mathrm{CH}_{2}, \mathrm{C}-\mathrm{O}-\mathrm{H}$ bending vibration, $\mathrm{C}-\mathrm{O}$ and $\mathrm{C}-\mathrm{C}$ stretching vibration, respectively. ${ }^{3}$ In the curve $c$ of Mo-polydopamine hybrid, two new adsorption bands are present at 1534 and $1429 \mathrm{~cm}^{-1}$, suggesting the formation of an indole structure. ${ }^{3}$ 

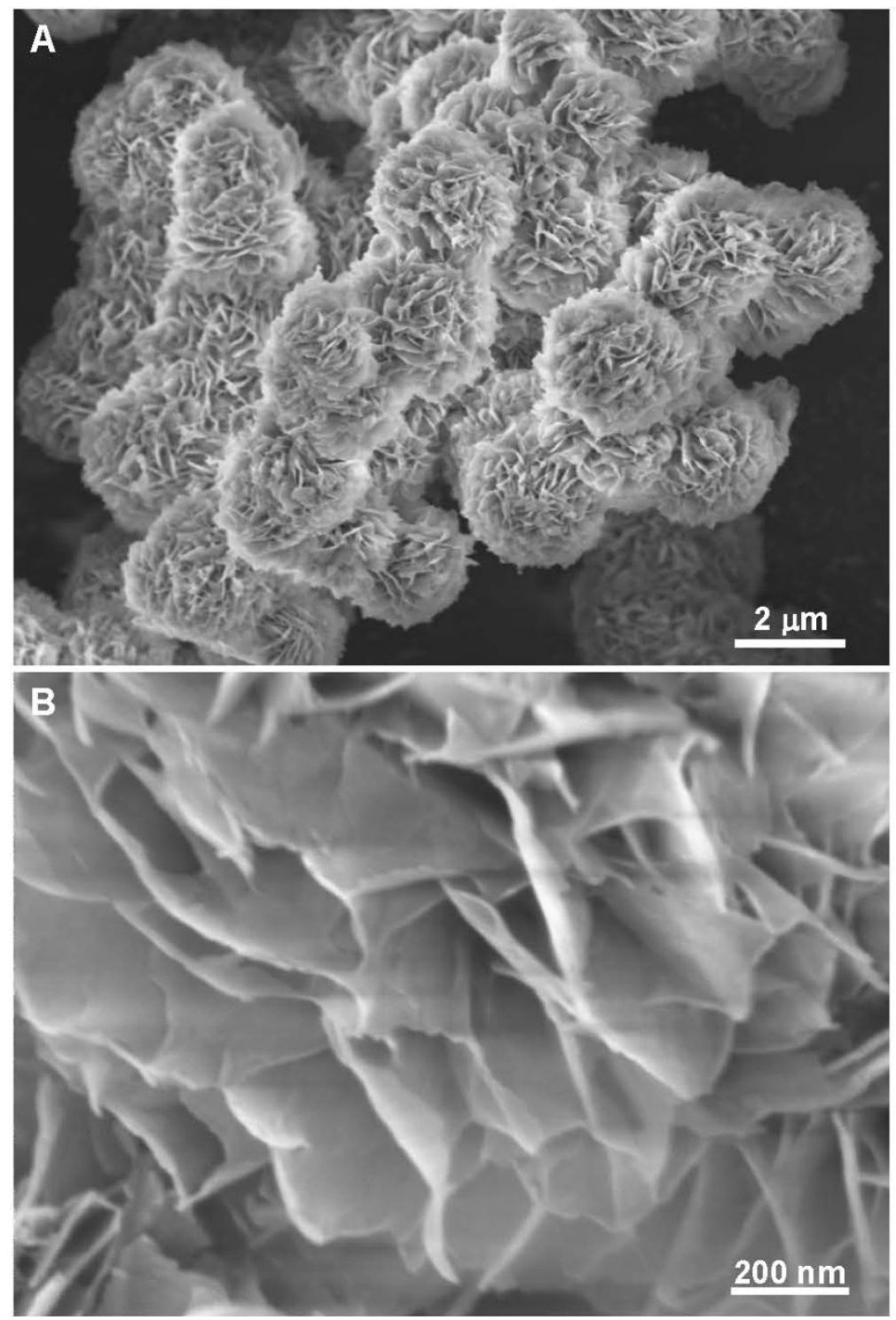

Figure S2. FESEM images $(A, B)$ of Mo-polydopamine hybrid precursor. 

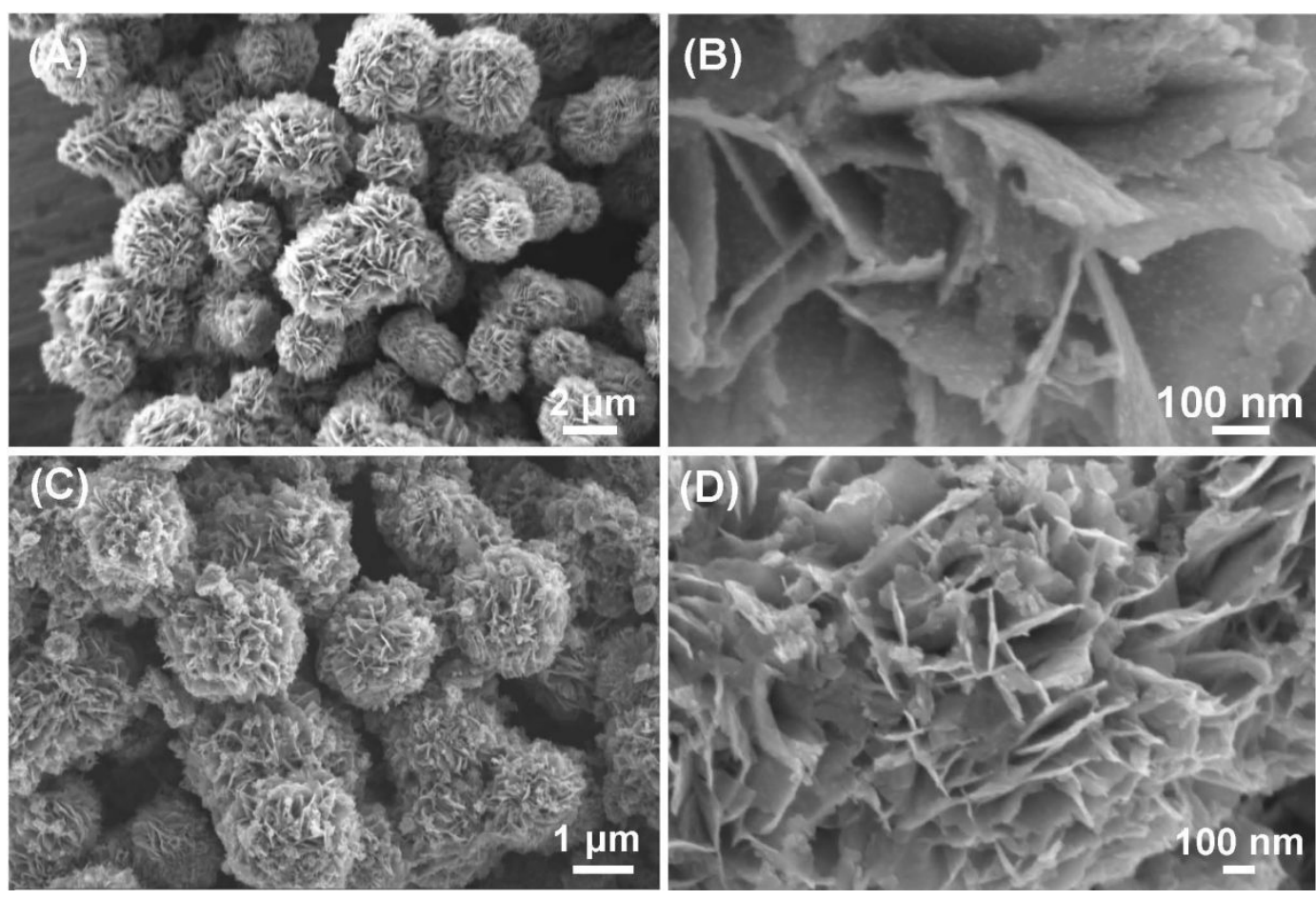

Figure S3. FESEM images of $\mathrm{MoSe}_{2} / \mathrm{NC}(\mathrm{A}, \mathrm{B})$ and $\mathrm{MoS}_{2} / \mathrm{NC}(\mathrm{C}, \mathrm{D})$ composites. 


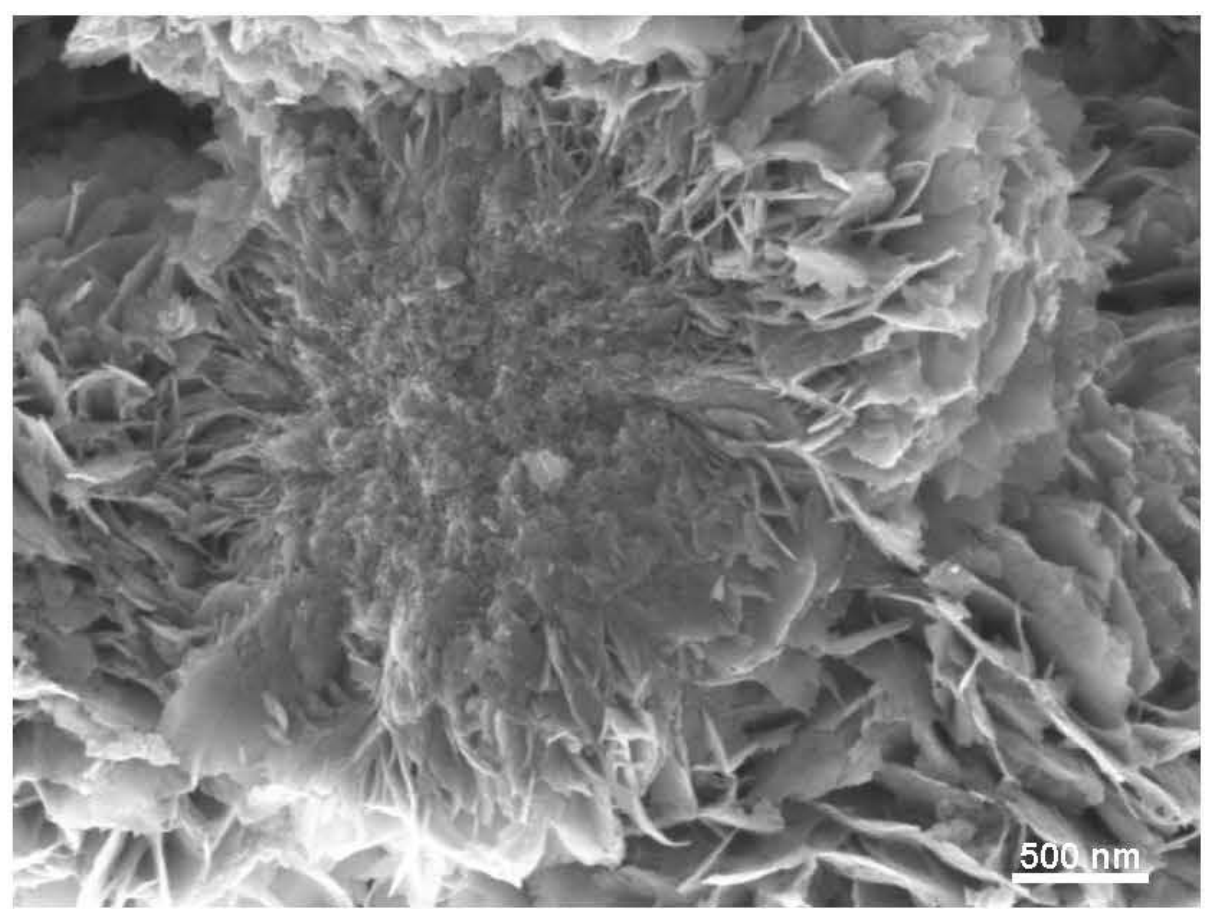

Figure S4. FESEM image of a cracked $\mathrm{MoS}_{0.74} \mathrm{Se}_{1.25} / \mathrm{NC}$ hierarchical flowerlike microsphere. 


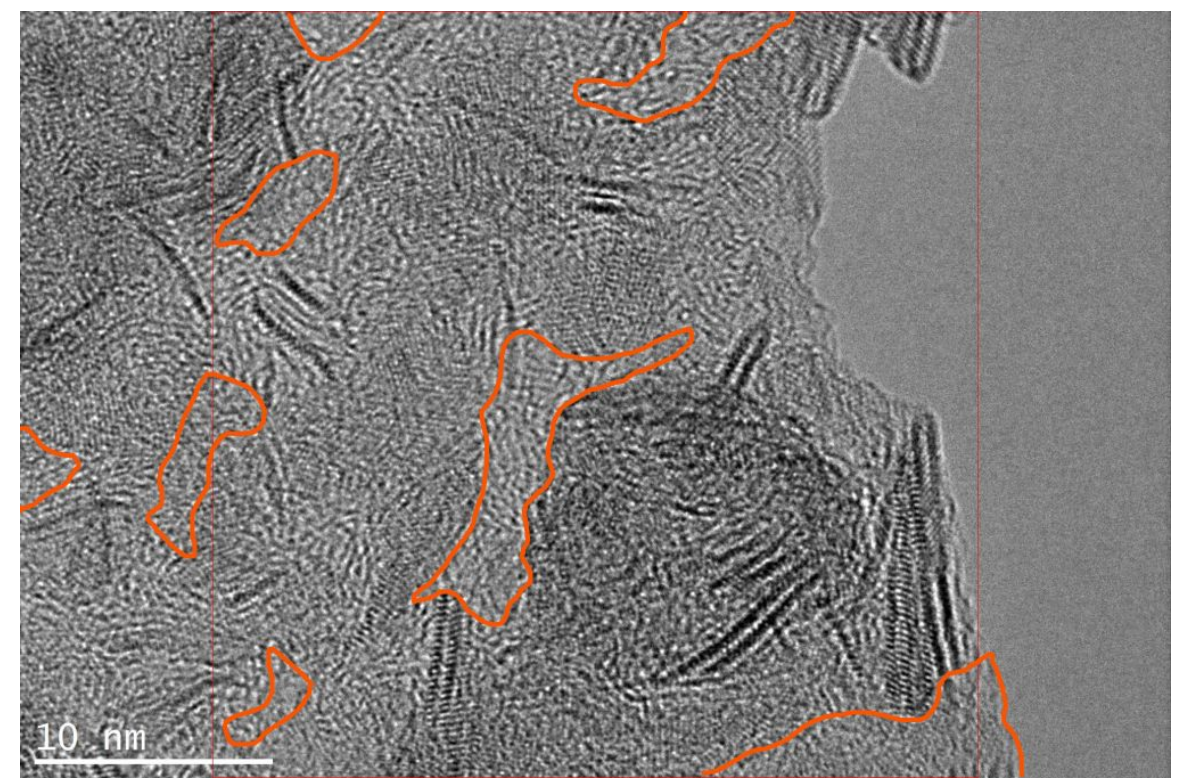

Figure S5. A typical HRTEM image of $\mathrm{MoS}_{0.74} \mathrm{Se}_{1.26} / \mathrm{NC}$. 


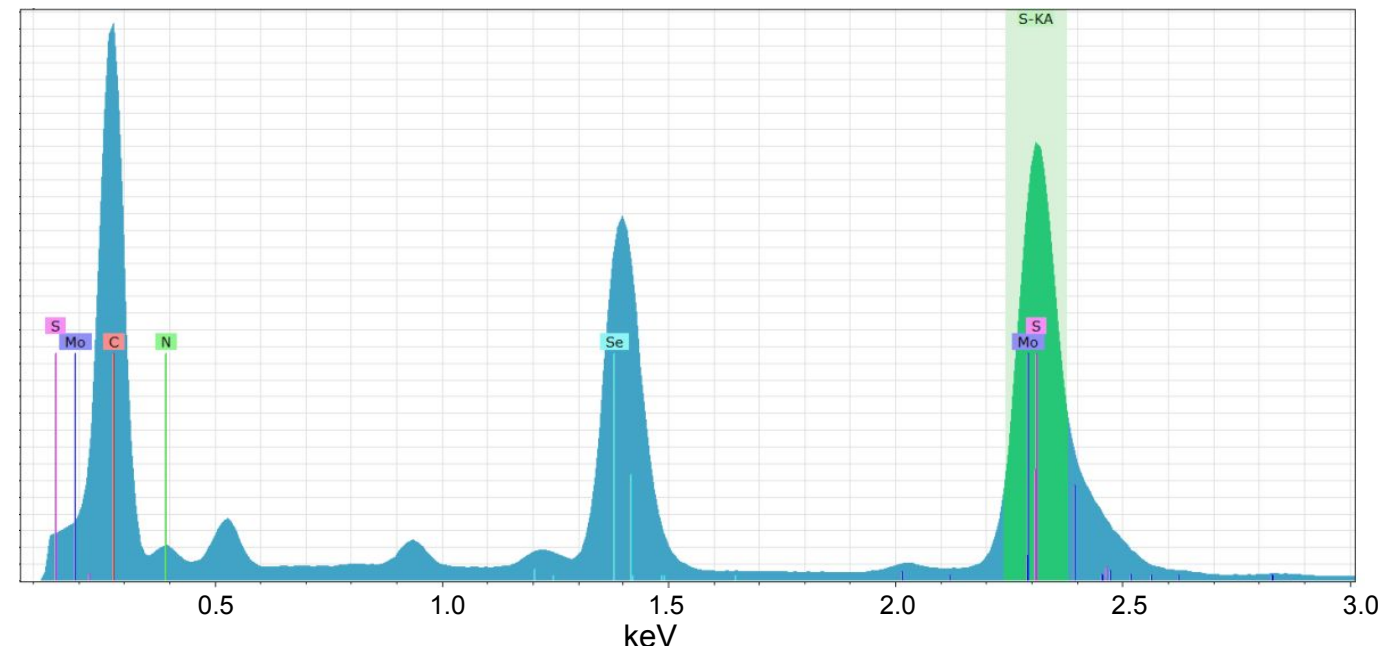

Figure S6. EDX spectrum of the as-fabricated $\mathrm{MoS}_{0.74} \mathrm{Se}_{1.26} / \mathrm{NC}$ flowerlike hierarchical microspheres. 


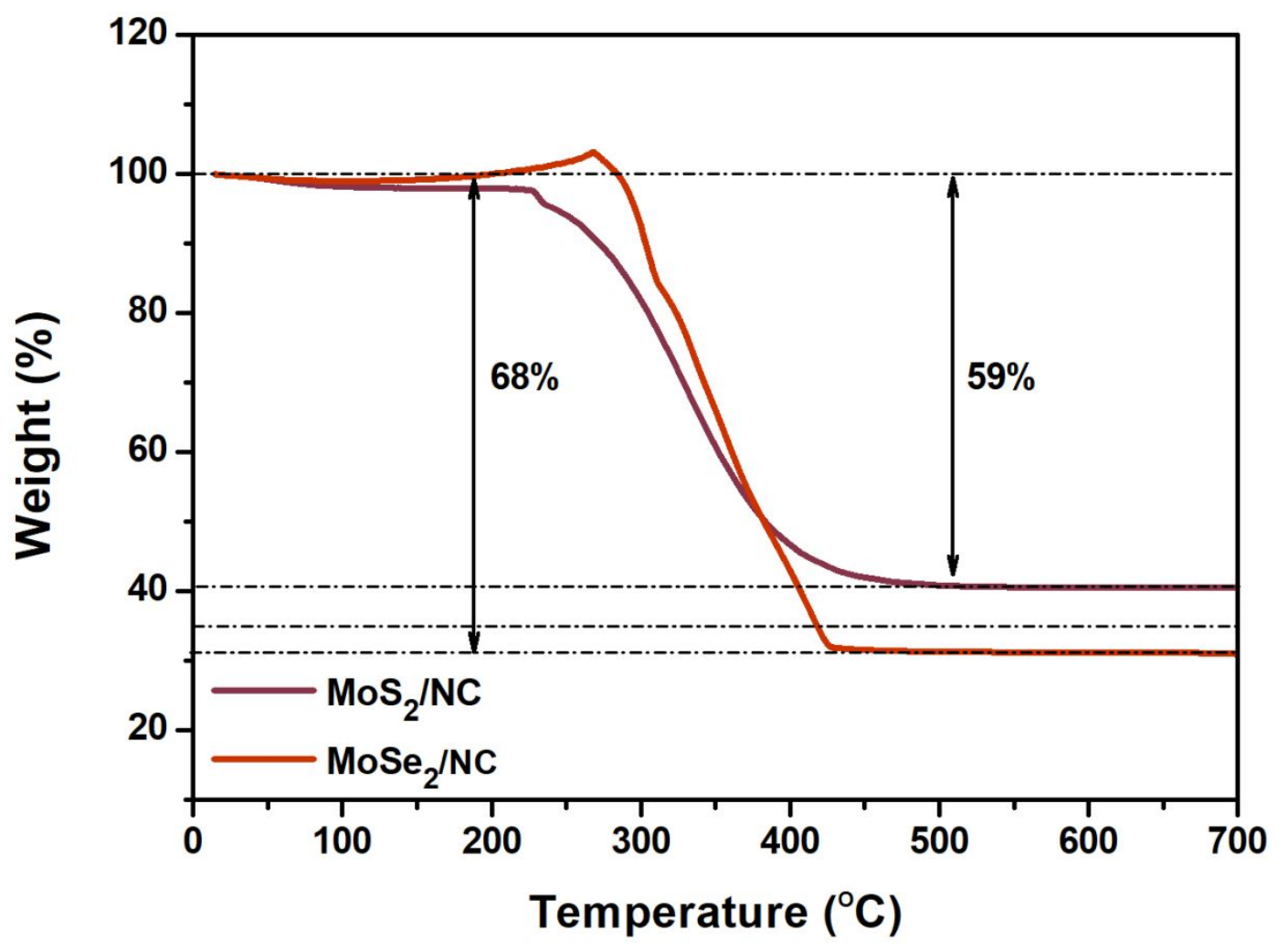

Figure S7. The TGA curves of $\mathrm{MoSe}_{2} / \mathrm{NC}$ and $\mathrm{MoS}_{2} / \mathrm{NC}$. 

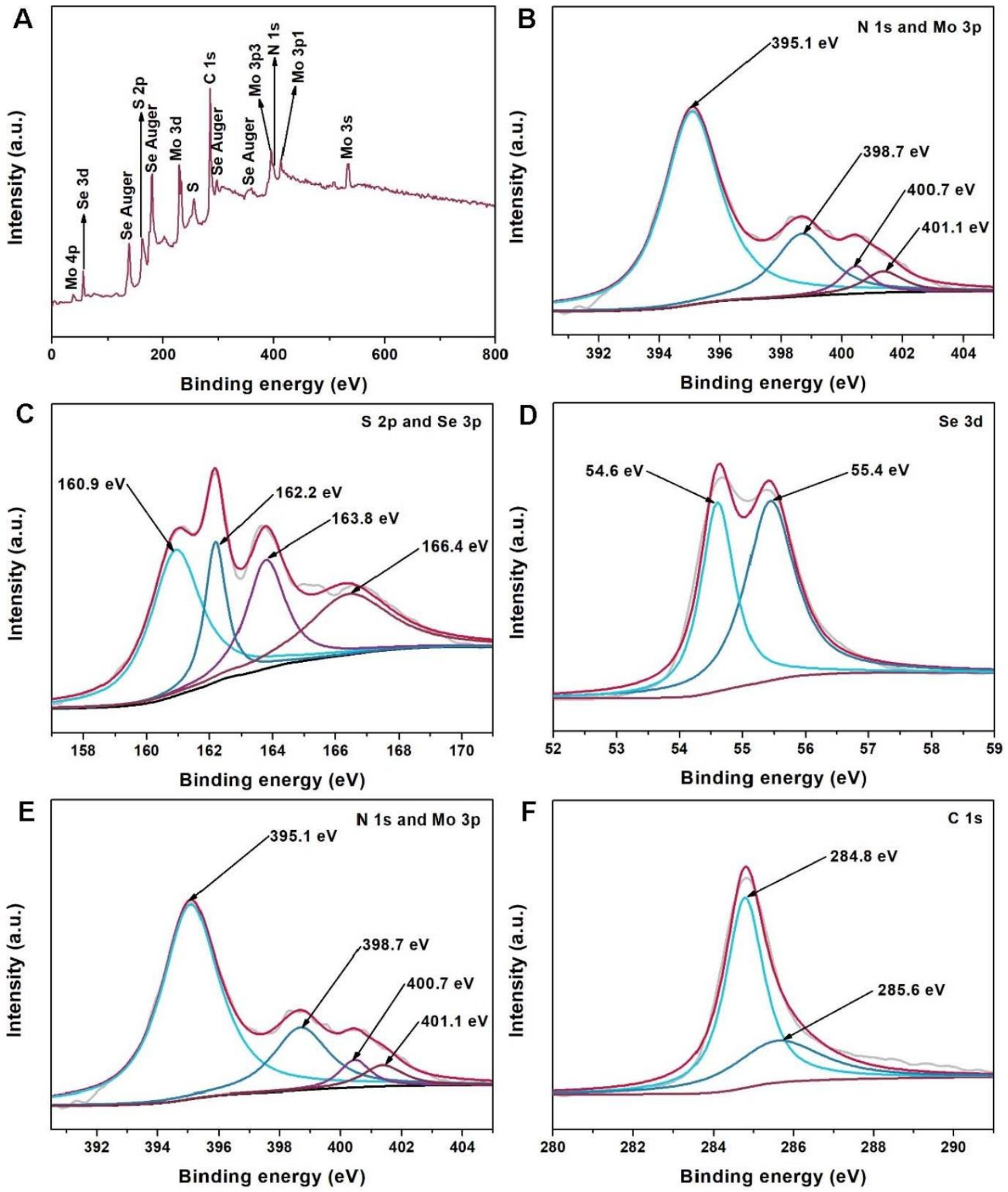

Figure S8. The XPS spectra of $\mathrm{MoS}_{0.74} \mathrm{Se}_{1.26} / \mathrm{NC}$ : (A) survey, (B-F) high-resolution spectra of Mo 3d, S 2p, Se 3d, N 1s and C 1s. 

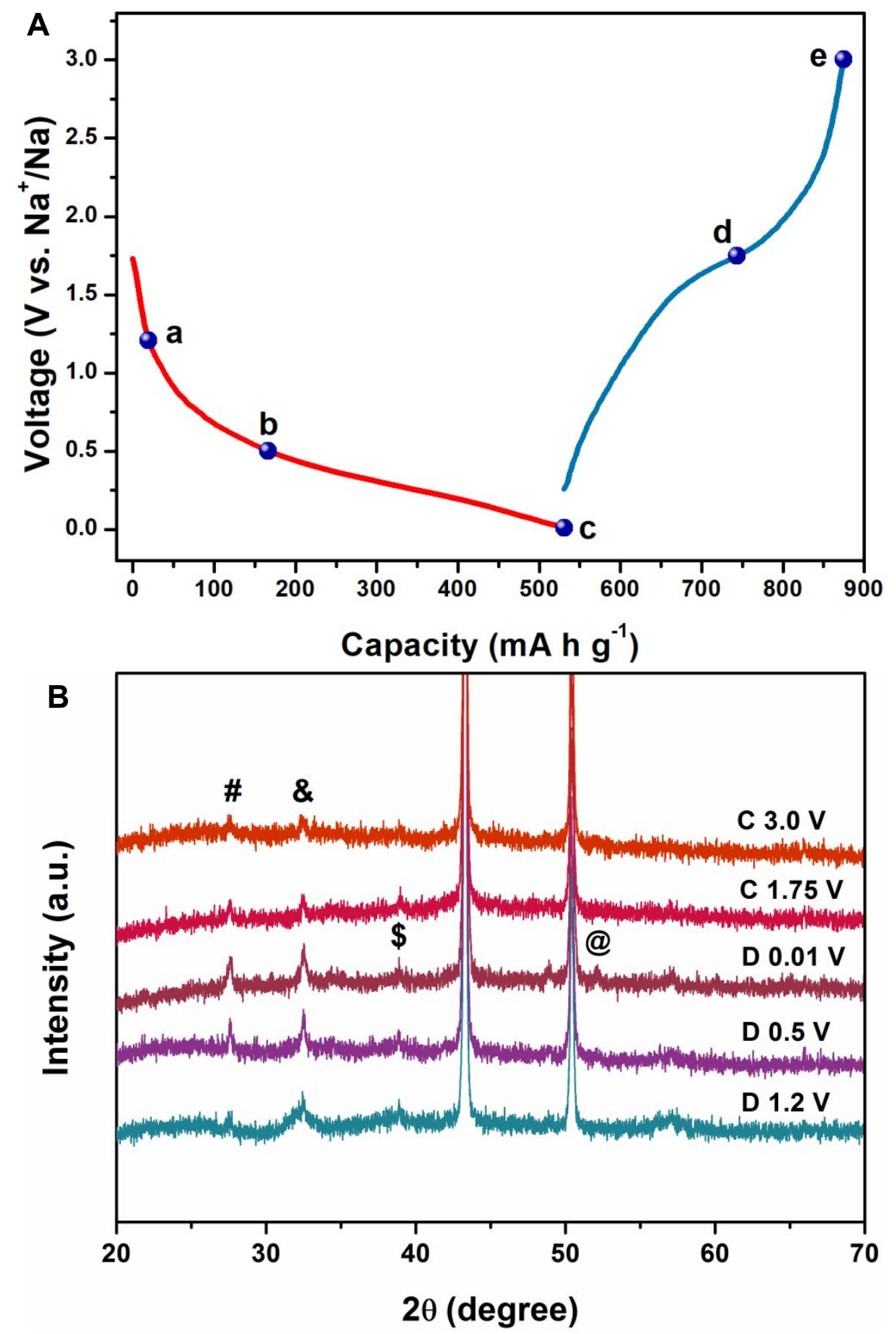

Figure S9. (A) The discharge/charge voltage curves for the first cycle at the current density of $500 \mathrm{~mA} \mathrm{~g}^{-1}$ and (B) ex-situ XRD patterns (Discharge: $1.2 \mathrm{~V}(\mathrm{a}), 0.5 \mathrm{~V}$ (b), $0.01 \vee(c)$; Charge: $1.75 \vee(d), 3.0 \vee(e))$ of the $\mathrm{MoS}_{0.74} \mathrm{Se}_{1.26} / \mathrm{NC}$ electrode corresponding to the selected sites in Figure S9A. 


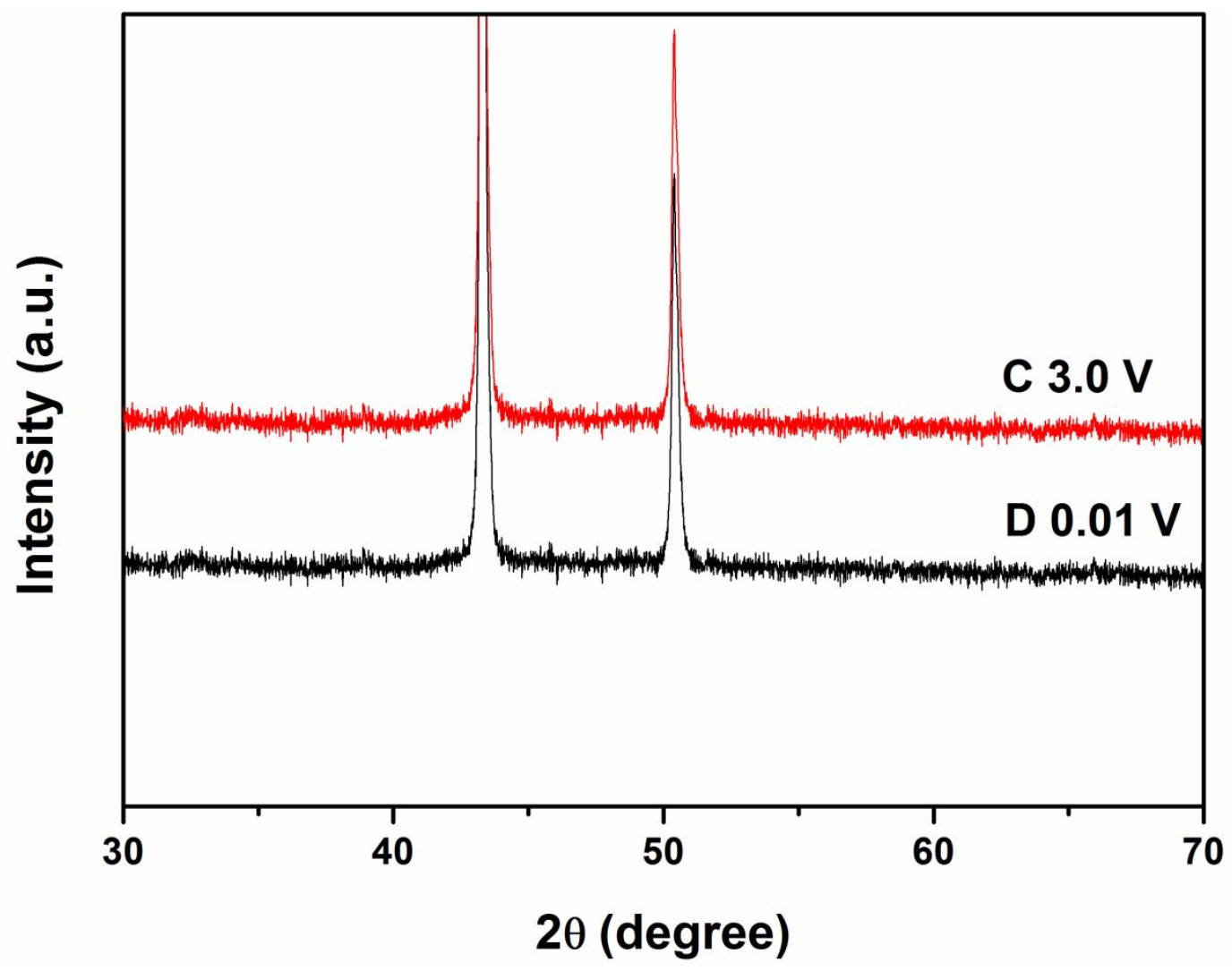

Figure S10. The XRD patterns of the $\mathrm{MoS}_{0.74} \mathrm{Se}_{1.26} / \mathrm{NC}$ electrode discharged to 0.01 $\mathrm{V}$ and charged to $3.0 \mathrm{~V}$ after 10 cycles at the current density of $500 \mathrm{~mA} \mathrm{~g}^{-1}$. 


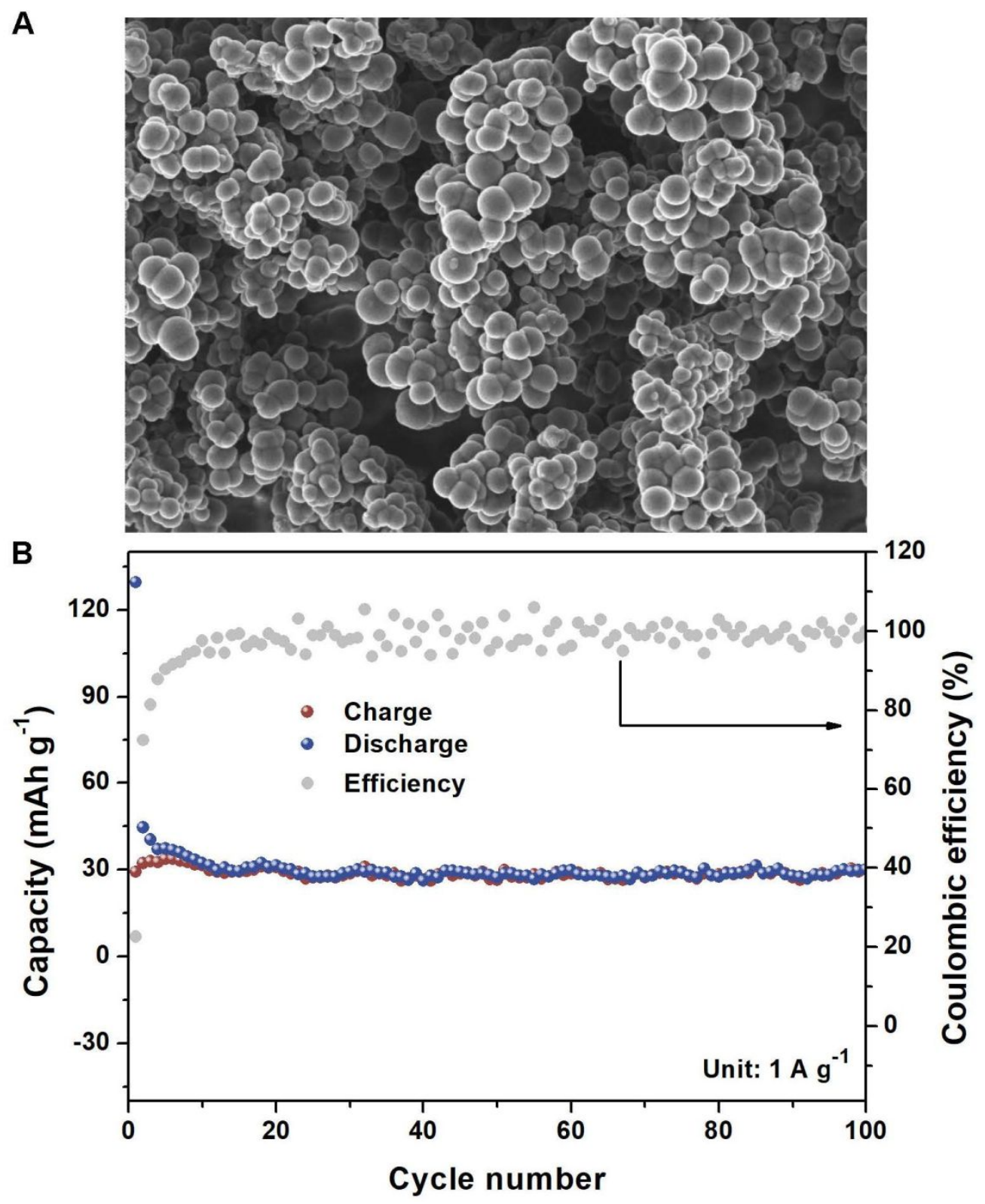

Figure S11. (A) FESEM image of NC, (B) cycling performance of the NC electrode at the current density of $1 \mathrm{~A} \mathrm{~g}^{-1}$. 


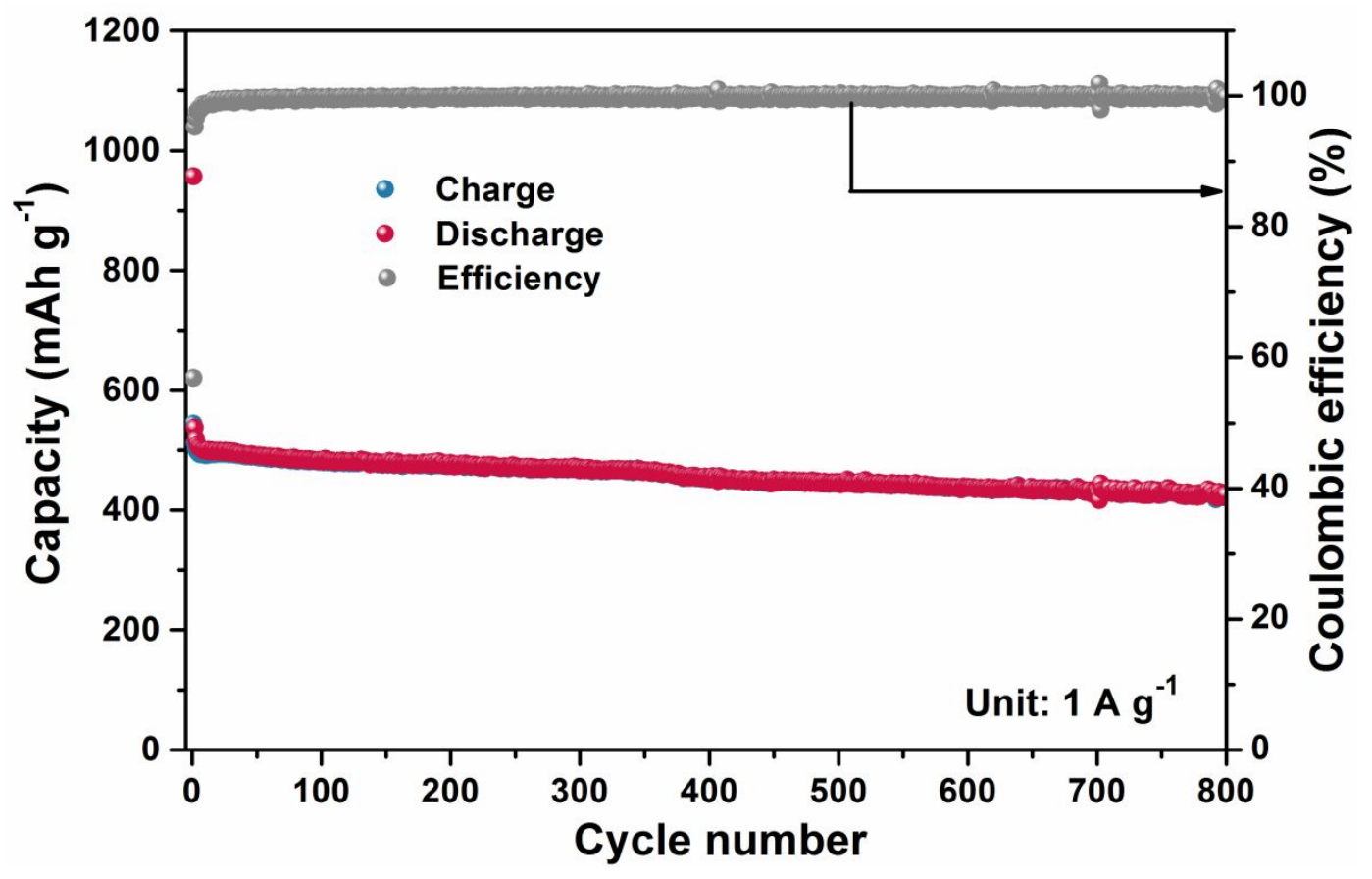

Figure S12. The cycling performance of $\mathrm{MoS}_{0.74} \mathrm{Se}_{1.26} / \mathrm{NC}$ with the areal mass of $\mathrm{MoS}_{0.74} \mathrm{Se}_{1.26}$ to be $1.2 \mathrm{mg} \mathrm{cm}^{-2}$. 

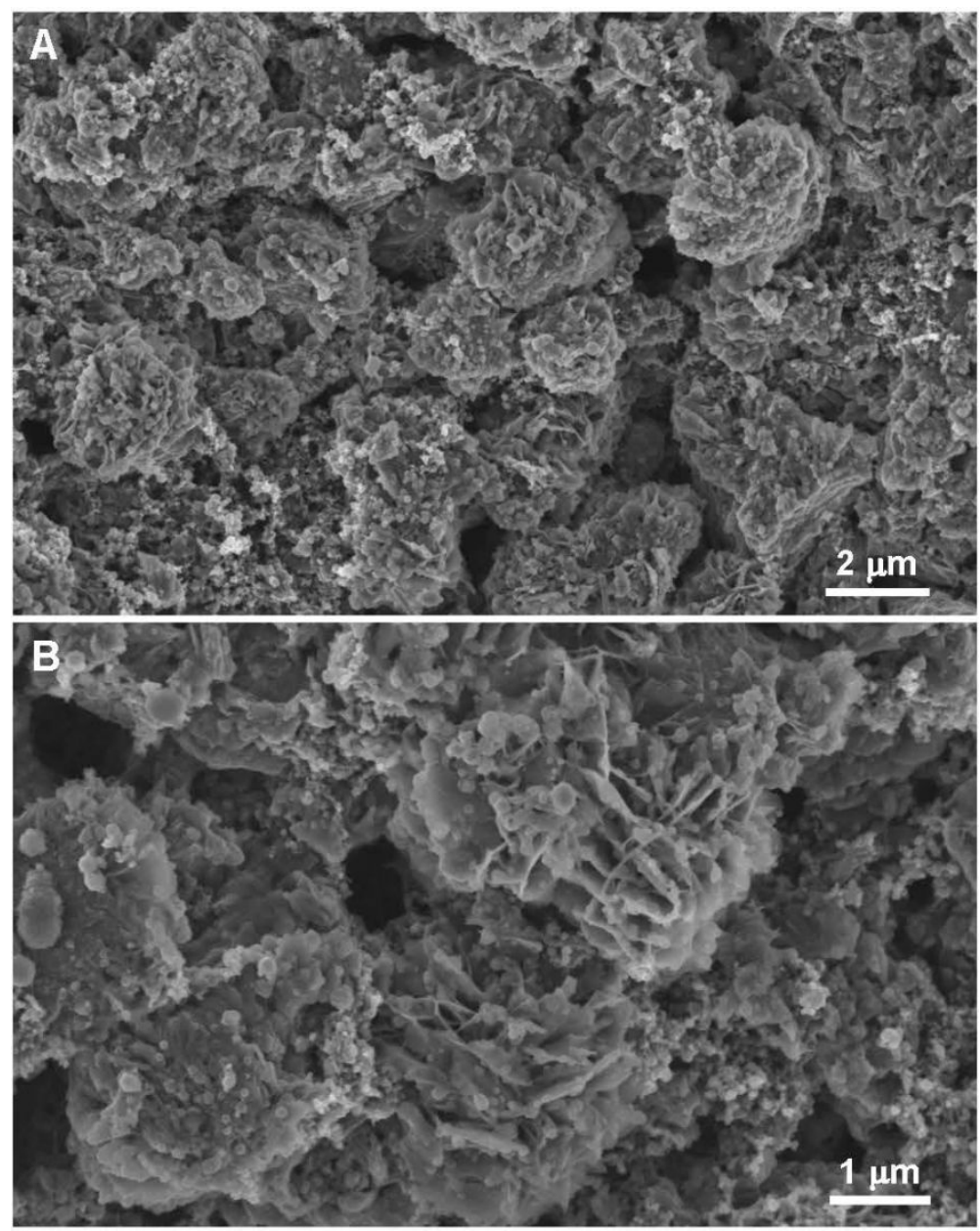

Figure S13. FESEM images $(A, B)$ of the $\mathrm{MoS}_{0.74} \mathrm{Se}_{1.26} / \mathrm{NC}$ electrode after 100 cycles at the current density of $1 \mathrm{~A} \mathrm{~g} \mathrm{~g}^{-1}$. 


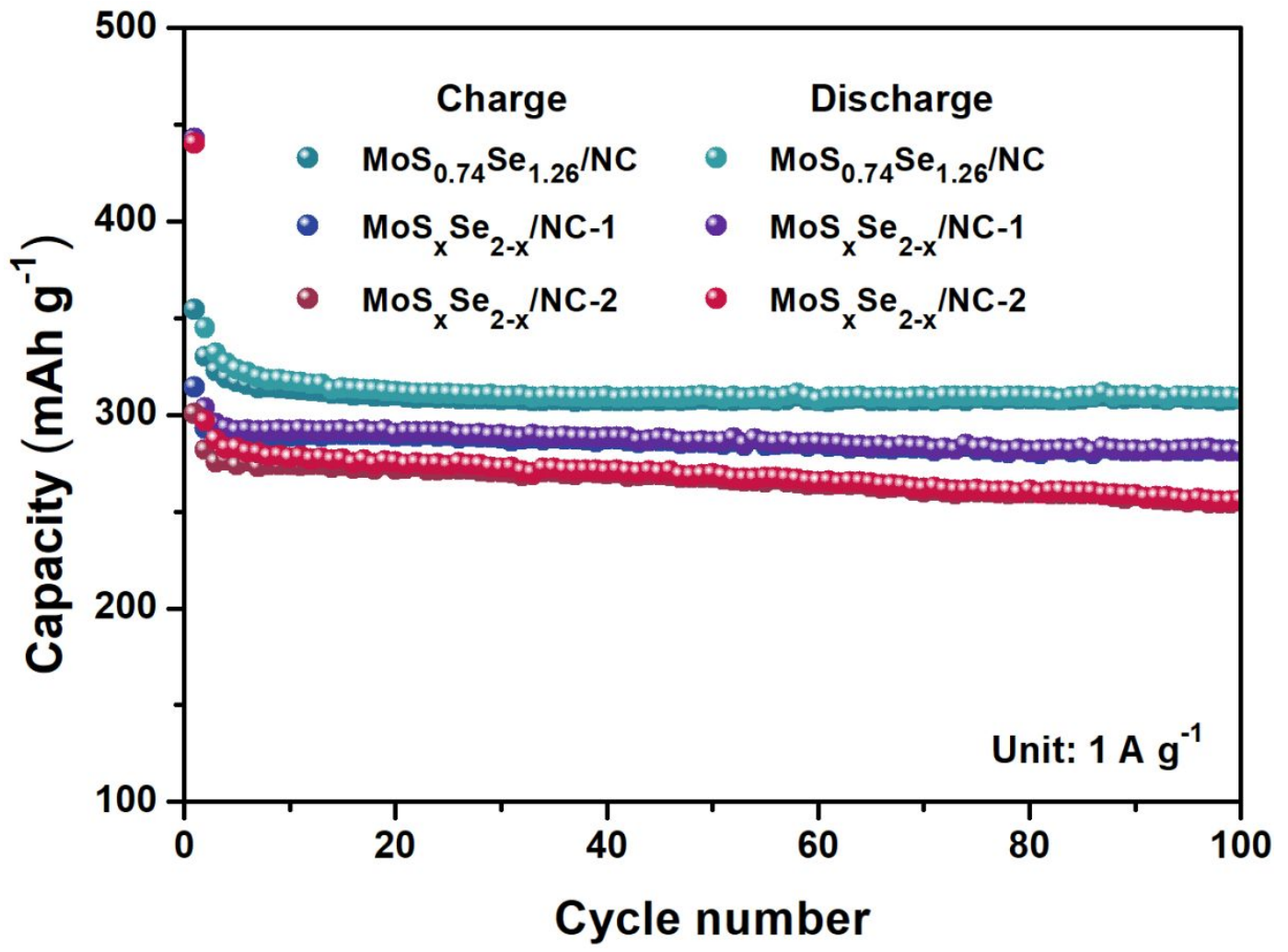

Figure S14. The cycling performance of $\mathrm{MoS}_{0.74} \mathrm{Se}_{1.26} / \mathrm{NC}, \mathrm{MoS}_{x} \mathrm{Se}_{2-x} / \mathrm{NC}-1$, and $\mathrm{MoS}_{\mathrm{x}} \mathrm{Se}_{2-\mathrm{x}} / \mathrm{NC}-2$ at the current density of $1 \mathrm{~A} \mathrm{~g}^{-1}$. 

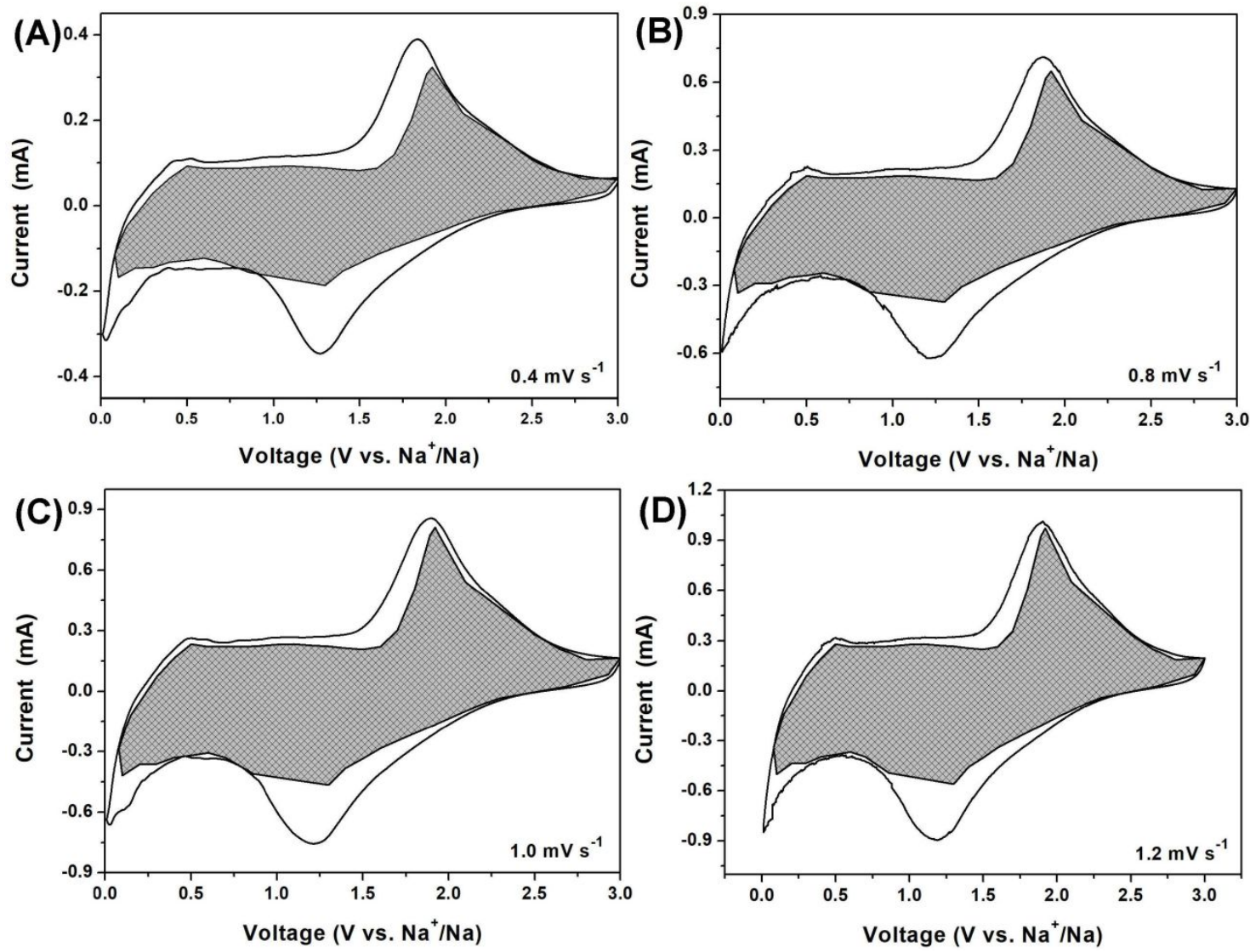

Figure S15. The capacitive contribution (shaded region) of $\mathrm{MoS}_{0.74} \mathrm{Se}_{1.26} / \mathrm{NC}$ at the scan rate of $0.4(A), 0.8(B), 1.0(C)$ and $1.2 \mathrm{mV} \mathrm{s}^{-1}(\mathrm{D})$, respectively. 

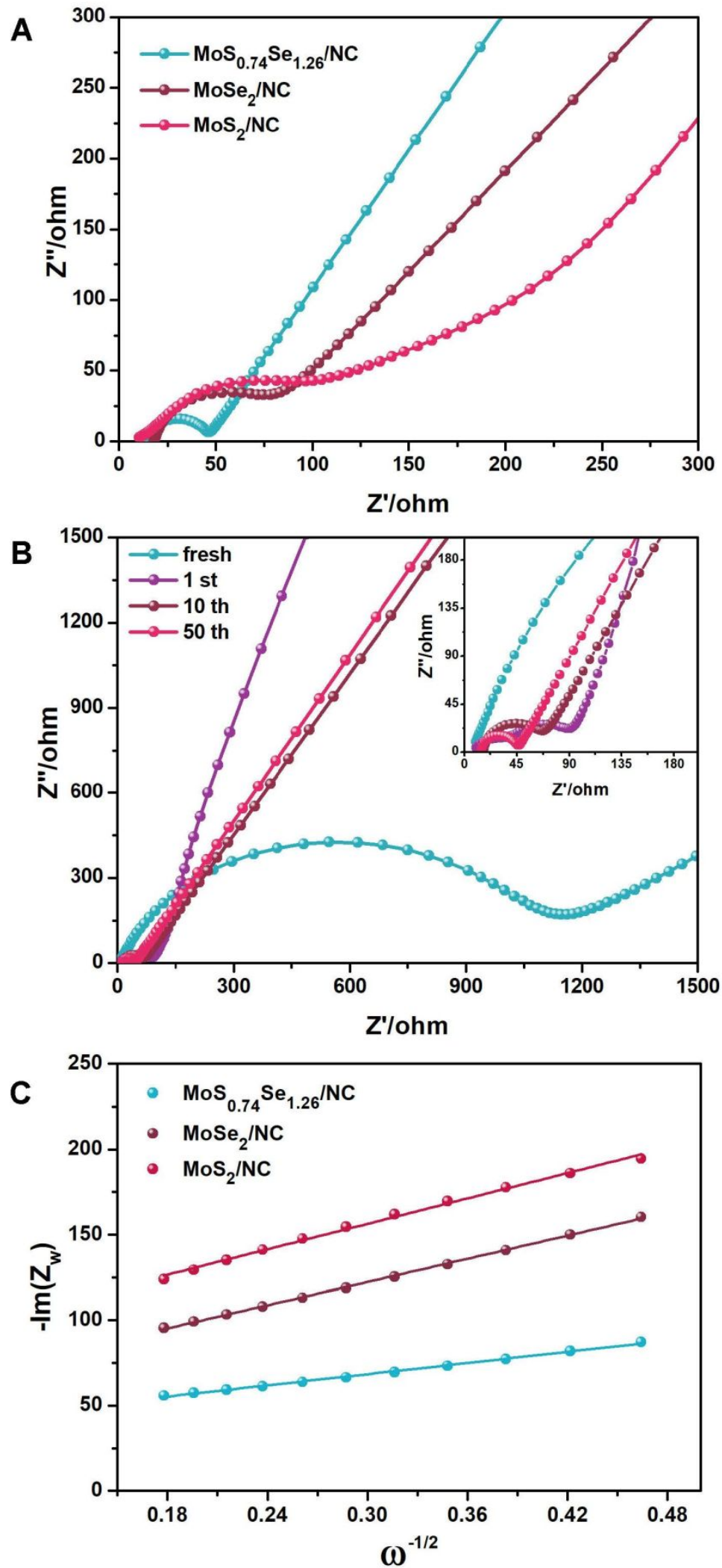

Figure S16. (A) The electrochemical impedance spectra (EIS) of fresh $\mathrm{MoS}_{0.74} \mathrm{Se}_{1.26} / \mathrm{NC}, \mathrm{MoSe}_{2} / \mathrm{NC}$ and $\mathrm{MoS}_{2} / \mathrm{NC}$ in the frequency range from $100 \mathrm{kHz}$ to $0.01 \mathrm{~Hz}$, (B) The EIS of $\mathrm{MoS}_{0.74} \mathrm{Se}_{1.26} / \mathrm{NC}$ after different discharge/charge cycles at 
$500 \mathrm{~mA} \mathrm{~g}^{-1},(\mathrm{C})$ the plots of $\omega^{-1 / 2}$ vs. $-\operatorname{Im}\left(Z_{\mathrm{w}}\right)$ according to Figure S16A.

Note: In order to evaluate the diffusion kinetics, we have been calculated the diffusion coefficient of $\mathrm{Na}^{+}\left(\mathrm{D}_{\mathrm{Na}+}\right)$ based on the low frequency EIS (based on Fig. S16A) according to the equations below: 4,5

$\mathrm{D}_{\mathrm{Na+}}=0.5\left(\mathrm{RT} / \mathrm{AF}{ }^{2} \mathrm{C} \sigma\right)^{2}$

$-\operatorname{Im}\left(\mathrm{Z}_{\mathrm{w}}\right)=\sigma \omega^{-1 / 2}$

$\operatorname{Re}\left(Z_{w}\right)=\sigma \omega^{-1 / 2}$

There, $\mathrm{D}$ is the diffusion coefficient, $\mathrm{R}$ is the gas constant, $\mathrm{T}$ is the temperature, $\mathrm{A}$ is the area of electrode, $\mathrm{F}$ is the Faraday constant, $\mathrm{C}$ is the $\mathrm{Na}^{+}$concentration, $\sigma$ is the Warburg coefficient. $\sigma$ could be obtained from the slope of $-\operatorname{Im}\left(Z_{\mathrm{w}}\right)$ vs. $\omega^{-1 / 2}$ or $\operatorname{Re}\left(Z_{\mathrm{w}}\right)$ vs. $\omega^{-1 / 2}$, and $\omega$ is the angular frequency. As shown is Fig. S16C, the $\sigma$ values of $\mathrm{MoS}_{0.74} \mathrm{Se}_{1.26} / \mathrm{NC}, \mathrm{MoSe}_{2} / \mathrm{NC}$ and $\mathrm{MoS}_{2} / \mathrm{NC}$ are 109.43, 225.96 and 244.30, respectively. According to equation (1), $\sigma^{-2}$ is proportional to $D_{\mathrm{Na}+}$. Hence, the $D_{\mathrm{Na}}$ of $\mathrm{MoS}_{0.74} \mathrm{Se}_{1.26} / \mathrm{NC}$ is four times as high as that of $\mathrm{MoSe}_{2} / \mathrm{NC}$ or $\mathrm{MoS}_{2} / \mathrm{NC}$, suggesting the $\mathrm{D}_{\mathrm{Na}}$ in $\mathrm{MoS}_{0.74} \mathrm{Se}_{1.26} / \mathrm{NC}$ cell is higher than that of $\mathrm{MoSe}_{2} / \mathrm{NC}$ and $\mathrm{MoS}_{2} / \mathrm{NC}$, demonstrating the better $\mathrm{Na}^{+}$diffusion kinetics of $\mathrm{MoS}_{0.74} \mathrm{Se}_{1.26} / \mathrm{NC}$. 


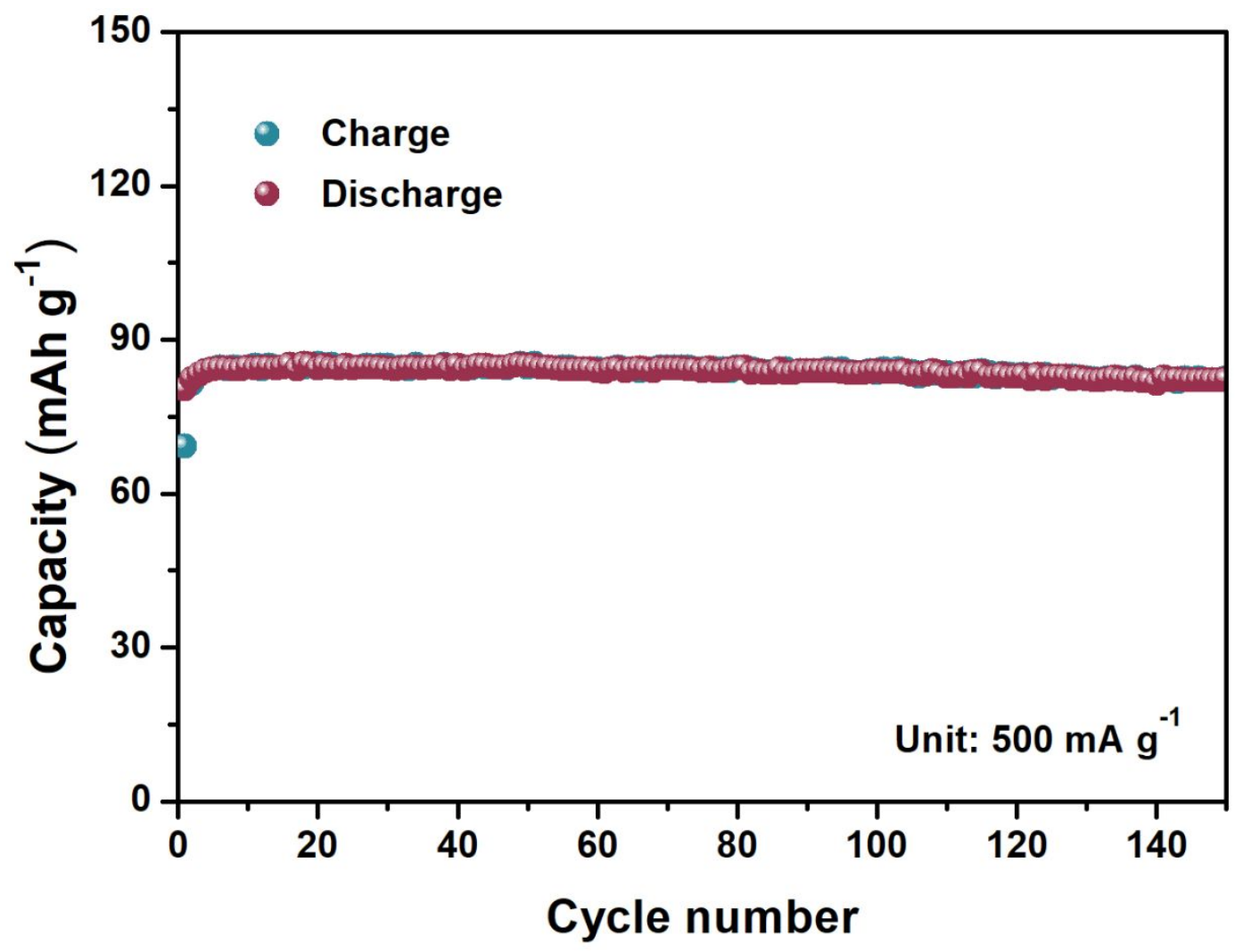

Figure S17. The cycling performance of Prussian Blue with the sodium foil as the counter electrode at the current density of $500 \mathrm{~mA} \mathrm{~g}^{-1}$. 

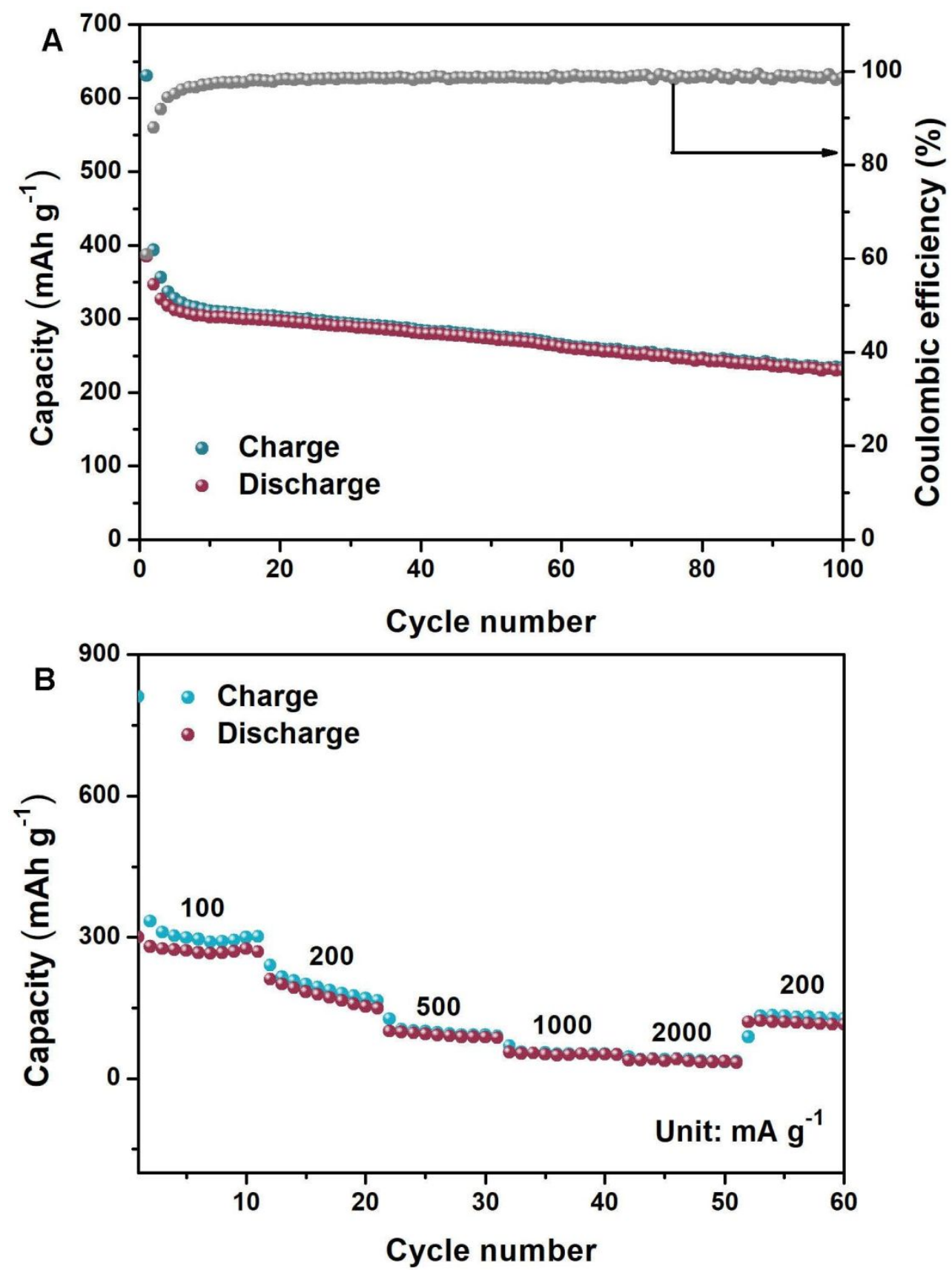

Figure S18. (A) Cycling performance and (B) rate capability of $\mathrm{MoS}_{0.74} \mathrm{Se}_{1.26} / \mathrm{NC} / /$ Prussian Blue Na-ion full cells at the current density of $500 \mathrm{~mA} \mathrm{~g}^{-1}$ (the capacity is calculated based on the mass of $\left.\mathrm{MoS}_{0.74} \mathrm{Se}_{1.26} / \mathrm{NC}\right)$. 
Table S1. The comparison of cyclability and rate capability between $\mathrm{MoS}_{0.74} \mathrm{Se}_{1.26} / \mathrm{NC}$ and other relevant electrode materials in SIBs.

\begin{tabular}{|c|c|c|c|}
\hline Active Materials & Capacity, cycles (mAh g $\left.{ }^{-1}\right)$ & Rate capability (mAh g ${ }^{-1}$ ) & Refs. \\
\hline \multirow{2}{*}{$\mathrm{MoS}_{0.74} \mathrm{Se}_{1.26} / \mathrm{NC}$} & $277.7,800$ cycles $\left(1 \mathrm{~A} \mathrm{~g}^{-1}\right)$ & \multirow{2}{*}{$195.8\left(15 \mathrm{~A} \mathrm{~g}^{-1}\right)$} & This \\
\hline & $246.7,1000$ cycles $\left(2 \mathrm{~A} \mathrm{~g}^{-1}\right)$ & & work \\
\hline $\mathrm{Mo}\left(\mathrm{Se}_{0.85} \mathrm{~S}_{0.15}\right)_{2}: \mathrm{C}$ & 312,100 cycles $\left(1 \mathrm{~A} \mathrm{~g}^{-1}\right)$ & $360\left(2 \mathrm{~A} \mathrm{~g}^{-1}\right)$ & 6 \\
\hline $\mathrm{MoS}_{2-x} \mathrm{Se}_{x} / \mathrm{GF}$ & 160,500 cycles $\left(0.2 \mathrm{~A} \mathrm{~g}^{-1}\right)$ & $110\left(5 \mathrm{~A} \mathrm{~g}^{-1}\right)$ & 7 \\
\hline $\mathrm{MoS}_{2}$ nanosheets & 155,100 cycles $\left(0.02 \mathrm{~A} \mathrm{~g}^{-1}\right)$ & $115\left(0.8 \mathrm{~A} \mathrm{~g}^{-1}\right)$ & 8 \\
\hline MoS-GC & 251,500 cycles $\left(2 \mathrm{~A} \mathrm{~g}^{-1}\right)$ & $381\left(2 \mathrm{~A} \mathrm{~g}^{-1}\right)$ & 9 \\
\hline $\mathrm{MoS}_{2}$ nanosheets & 251,100 cycles $\left(0.32 \mathrm{~A} \mathrm{~g}^{-1}\right)$ & $300\left(0.32 \mathrm{~A} \mathrm{~g}^{-1}\right)$ & 10 \\
\hline $\mathrm{CC} @ \mathrm{CN} @ \mathrm{MoS}_{2}$ & 2651000 cycles $\left(1 \mathrm{~A} \mathrm{~g}^{-1}\right)$ & $235\left(2 \mathrm{~A} \mathrm{~g}^{-1}\right)$ & 11 \\
\hline G- $\mathrm{MoS}_{2}$ & 175,400 cycles $\left(2 \mathrm{~A} \mathrm{~g}^{-1}\right)$ & $250\left(2 \mathrm{~A} \mathrm{~g}^{-1}\right)$ & 12 \\
\hline Tulip- $\mathrm{MoS}_{2} / \mathrm{NG}$ & 179,1000 cycles $\left(1 \mathrm{~A} \mathrm{~g}^{-1}\right)$ & $216\left(5 \mathrm{~A} \mathrm{~g}^{-1}\right)$ & 13 \\
\hline $\mathrm{MoSe}_{2}$ nanotube & 228,1500 cycles $\left(1 \mathrm{~A} \mathrm{~g}^{-1}\right)$ & $220\left(2 \mathrm{~A} \mathrm{~g}^{-1}\right)$ & 14 \\
\hline $\mathrm{MoSe}_{2} / \mathrm{C}_{\text {cas }}$ & 358.3350 cycles $\left(0.5 \mathrm{~A} \mathrm{~g}^{-1}\right)$ & $261\left(4 \mathrm{~A} \mathrm{~g}^{-1}\right)$ & 15 \\
\hline $\mathrm{MoS}_{2} @ \mathrm{RGO}$ & 284,160 cycles $\left(1 \mathrm{~A} \mathrm{~g}^{-1}\right)$ & $260\left(2 \mathrm{~A} \mathrm{~g}^{-1}\right)$ & 16 \\
\hline E-MoS 2 carbon fibers & 241,700 cycles $\left(1 \mathrm{~A} \mathrm{~g}^{-1}\right)$ & $104\left(20 \mathrm{~A} \mathrm{~g}^{-1}\right)$ & 17 \\
\hline $\mathrm{PEO}_{2 \mathrm{~L}}-\mathrm{MoS}_{2}$ & 119,70 cycles $\left(0.05 \mathrm{~A} \mathrm{~g}^{-1}\right)$ & $112\left(1 \mathrm{~A} \mathrm{~g}^{-1}\right)$ & 18 \\
\hline $\mathrm{MoS}_{2} @ \mathrm{C}-\mathrm{CMC}$ & 286,100 cycles $\left(0.08 \mathrm{~A} \mathrm{~g}^{-1}\right)$ & $205\left(1 \mathrm{~A} \mathrm{~g}^{-1}\right)$ & 19 \\
\hline $\mathrm{MoS}_{2} @ A M C R s$ & 305,300 cycles $\left(1 \mathrm{~A} \mathrm{~g}^{-1}\right)$ & $302\left(2 \mathrm{~A} \mathrm{~g}^{-1}\right)$ & 20 \\
\hline
\end{tabular}

\section{References}

(1) Ail, T.; Al-Thabaiti, S.; Alyoubi, A.; Mokhtar, M. Copper Substituted Heteropolyacid Catalysts for the Selective Dehydration of Ethanol. J. Alloy. Comp. 2010, 496, $553-559$.

(2) Abu-Zied, B.; Farrag, A.; Asiri, A. Preparation of Caesium-Substituted Phosphomolybdic Acid Via Solid-State Ion Exchange Method. Powder Technology 2013, 246, 643-649.

(3) Zhao, C.; Kong, J.; Yang, L.; Yao, X.; Phua, S.; Lu, X. The Dopamine-MovI 
Complexation-Assisted Large-Scale Aqueous Synthesis of a Single-Layer $\mathrm{MoS}_{2} /$ Carbon Sandwich Structure for Ultrafast, Long-Life Lithium-Ion Batteries. Chem. Commun. 2014, 50, 9672-9675.

(4) Meng, Y.; Wang, Y.; Zhang, Z.; Chen, X.; Guo, Y.; Xiao, D. A Phytic Acid Derived $\mathrm{LiMn}_{0.5} \mathrm{Fe}_{0.5} \mathrm{PO}_{4} /$ Carbon Composite of High Energy Density for Lithium Rechargeable Batteries. Sci. Rep. 2019, 9, 6665.

(5) Zhang, D.; Popov, B. N.; White, R. E. Electrochemical Investigation of $\mathrm{CrO}_{2.65}$ Doped $\mathrm{LiMn}_{2} \mathrm{O}_{4}$ as a Cathode Material for Lithium-Ion Batteries. J. Power Sources 1998, 76, 81-90.

(6) Shi, Z.-T.; Kang, W.; Xu, J.; Sun, L.-L.; Wu, C.; Wang, L.; Yu, Y.-Q.; Yu, Y. W.; Zhang, W.; Lee, C.-S. In Situ Carbon-Doped $\mathrm{Mo}\left(\mathrm{Se}_{0.85} \mathrm{~S}_{0.15}\right)_{2}$ Hierarchical Nanotubes as Stable Anodes for High-Performance Sodium-Ion Batteries. Small 2015, 11, $5667-5674$

(7) Jia, G.; Chao, D.; Tiep, N. H.; Zhang, Z.; Fan, H. J. Intercalation Na-Ion Storage in Two-Dimensional $\mathrm{MoS}_{2-\mathrm{x}} \mathrm{Se}_{\mathrm{x}}$ and Capacity Enhancement by Selenium Substitution. Energy Storage Mater. 2018, 14, 136-142.

(8) Bang, G. S.; Nam, K. W.; Kim, J. Y.; Shin, J.; Choi, J. W.; Choi, S.-Y. Effective Liquid-Phase Exfoliation and Sodium Ion Battery Application of $\mathrm{MoS}_{2}$ Nanosheets. ACS Appl. Mater. Interfaces 2014, 6, 7084-7089.

(9) Sahu, T. S.; Li, Q.; Wu, J.; Dravid, V. P.; Mitra, S. Exfoliated $\mathrm{MoS}_{2}$ Nanosheets Confined in 3-D Hierarchical Carbon Nanotube@Graphene Architecture with Superior Sodium-Ion Storage. J. Mater. Chem. A 2017, 5, 355-363. 
(10) Su, D.; Dou, S.; Wang, G. Ultrathin $\mathrm{MoS}_{2}$ Nanosheets as Anode Materials for Sodium-Ion Batteries with Superior Performance. Adv. Energy Mater. 2015, 5, 1401205

(11) Ren, W.; Zhang, H.; Guan, C.; Cheng, C. Ultrathin $\mathrm{MoS}_{2}$ Nanosheets@Metal Organic Framework-Derived N-Doped Carbon Nanowall Arrays as Sodium Ion Battery Anode with Superior Cycling Life and Rate Capability. Adv. Funct. Mater. 2017, 27, 172116.

(12) Yao, K.; Xu, Z.; Li, Z.; Liu, X.; Shen, X.; Cao, L.; Huang, J. Synthesis of Grain-like $\mathrm{MoS}_{2}$ for High-Performance Sodium-Ion Batteries. ChemSusChem 2018, 11, 2130-2137.

(13) Wang, T.; Shen, X.; Huang, J.; Xi, Q.; Zhao, Y.; Guo, Q.; Wang, X.; Xu, Z.; Tulip-Like $\mathrm{MoS}_{2}$ with a Single Sheet Tapered Structure Anchored on N-Doped Graphene Substrates Cia C-O-Mo Bonds for Superior Sodium Storage. J. Mater. Chem. A 2018, 6, 24433-24440.

(14) Zhang, J.; Wu, M.; Liu, T.; Kang, W.; Xu, J. Hierarchical Nanotubes Constructed from Interlayer-Expanded $\mathrm{MoSe}_{2}$ Nanosheets as a Highly Durable Electrode for Sodium Storage. J. Mater. Chem. A 2017, 5, 24859-24866.

(15) Li, J.; Hu, H.; Qin, F.; Zhang, P.; Zou, L.; Wang, H.; Zhang, K.; Lai, Y. Flower-like $\mathrm{MoSe}_{2} / \mathrm{C}$ Composite with Expanded (002) Planes of Few-layer MoSe2 as the Anode for High-Performance Sodium-Ion Batteries. Chem. Eur. J. 2017, 23, 14004-14010.

(16) Che, Z.; Li, Y.; Chen, K.; Wei, M.; Hierarchical MoS ${ }_{2} @ R G O$ Nanosheets for High Performance Sodium Storage. J. Power Sources 2016, 331, 50-57. 
(17) Zhao, C.; Yu, C.; Zhang, M.; Sun, Q.; Li, S.; Banis, M. N.; Han, X.; Dong, Q.; Yang, J.; Wang, G.; Sun, X.; Qiu, J. Enhanced Sodium Storage Capability Enabled by Super Wide-Interlayerspacing $\mathrm{MoS}_{2}$ Integrated on Carbon Fibers. Nano Energy 2017, $41,66-74$

(18) Li, Y.; Liang, Y.; Hernandez, F.; Yoo, H.; An, Q.; Yao, Y. Enhancing Sodium-Ion Battery Performance with Interlayer-Expanded $\mathrm{MoS}_{2}$-PEO Nanocomposites. Nano Energy 2015, 15, 453-461.

(19) Xie, X.; Makaryan, T.; Zhao, M.; Aken, K. L. V.; Gogotsi, Y.; Wang, G. MoS 2 Nanosheets Vertically Aligned on Carbon Paper: A Freestanding Electrode for Highly Reversible Sodium-Ion Batteries. Adv. Energy Mater. 2016, 6, 1502161.

(20) Pang, Y.; Zhang, S.; Liu, L.; Liang, J.; Sun, Z.; Wang, Y.; Xiao, C.; Ding, D.; Ding, S. Few-Layer $\mathrm{MoS}_{2}$ Anchored at Nitrogen-Doped Carbon Ribbons for Sodium-lon Battery Anodes with High Rate Performance. J. Mater. Chem. A 2017, 5, 17963-17972. 